\title{
Does government support enhance the relation between networking structure and sustainable competitive performance among SMEs?
}

Asem Alkahtani, Norfarah Nordin and Rizwan Ullah Khan *i]

* Correspondence:

rizwanhayat1989@gmail.com

Universiti Sains Malaysia, Graduate School of Business, 11800 USM

Penang, Malaysia

\begin{abstract}
Purpose: The underlining study's main objective is to examine how networking structure (density and centrality) affects sustainable competitive performance in Pakistan's SMEs.

Design/methodology/approach: Hence, small enterprises a significant source of economic development, employment, and value creation. Therefore, on the base of previous literature, we developed hypothesis related government financial support and network structure, and data collected through structured questionnaires from top management of SMEs.

Findings: The results indicate that density has a positive and significant effect on sustainable competitive performance, while centrality has an insignificant impact on SCP. Furthermore, government financial support strongly and significantly supports the relation between networking structure and SCP in Pakistan.

Practical implications: This research has several recommendations for the government to adequately support small enterprises because owners have a networking system at the local and international level but have a lack of environment.

Originality/value: Government plays a crucial role in small- and medium-sized enterprises boost performance and economic growth because it creates employment opportunities, poverty reduction, and economic development. Nevertheless, from the last decades, due to some organizational policies and environmental flexibility, SMEs face a lot of challenges which became a barrier such as lack of government subsidies, incentives, and taxes in emerging economies. To bridge the above challenges of SMES, the current study is conducted because before this there was no such literature who underline the current challenges in emerging economies.
\end{abstract}

Keywords: Density, Centrality, Government support, Sustainable competitive performance
(-) The Author(s). 2020 Open Access This article is licensed under a Creative Commons Attribution 4.0 International License, which permits use, sharing, adaptation, distribution and reproduction in any medium or format, as long as you give appropriate credit to the original author(s) and the source, provide a link to the Creative Commons licence, and indicate if changes were made. The images or other third party material in this article are included in the article's Creative Commons licence, unless indicated otherwise in a credit line to the material. If material is not included in the article's Creative Commons licence and your intended use is not permitted by statutory regulation or exceeds the permitted use, you will need to obtain permission directly from the copyright holder. To view a copy of this licence, visit http://creativecommons.org/licenses/by/4.0/. 


\section{Introduction}

In the current knowledge-based economy, small enterprises have become one of the most significant drivers of economic development, employment creation, and poverty reduction (Doh \& Kim, 2014). In Pakistan, more than 90\% are SMEs, and it significantly contribute $40 \%$ share to economic growth and create $70 \%$ employment opportunities (SMEDA 2018). Despite having a substantial contribution to economic growth, still, SMEs have a high failure rate across the globe as compared to neighbor countries, thereby Anwar, Khan, \& Khan, 2018 stated that 19\% new ventures fail after 5 years, but the remaining $25 \%$ survive up to 4 years, which has a negative impact on economic growth, employment rate, and employee living standard (Tahir, Batool, \& Takrim, 2016). Therefore, like Bilal, Khan, and Akoorie (2016) suggested that due to lack of resources and dynamic capabilities, an organization cannot gain sustainable competitive performance because resources (internal and external) are core drivers for SMEs survive in the underdeveloped economies (Joo \& Suh, 2017). Thereby, the current study examines the networking capability as external resources have direct impact on sustainable competitive performance.

In emerging economies, small enterprises waste their vigor on connectivity with external suppliers and customers (Han, Chung, Son, \& Kwon, 2017). Mostly in developing economies, small ventures rely on their internal resources which are insufficient to gain sustainable competitive advantage without governmental awareness and support (Hoque, 2018). Therefore, Tahir et al. (2016) scrutinized that government and political incentives are very crucial for SMEs support, and they offer external resources such as financial incentives, reliefs, and support for competitive advantage and opportunities recognition. Specifically, by reviewing how each government-supporting component can interact with a network structure (Pruthi \& Wright, 2017), we will be able to understand more regarding how both concepts enhance and relate performance. Smalland medium-sized enterprises are desired to connect with financial and non-financial institutions of government bodies to build networking culture with an international organization and find new opportunities in the market (Songling, Ishtiaq, Anwar, \& Ahmed, 2018), because lack of external resources of SMEs with external suppliers and customers are significantly affected through the unavailability of support from the government (Bilal et al., 2016; Mbonyane \& Ladzani, 2011).

Therefore, despite several noteworthy kinds of literature, Wang \& Fang, 2012; Hoque, 2018 postulated that network structures have a significant driver for SME's to enhance their performance, but mostly researcher focus to study the context in the developed economies, because in developed economies, the government provide equal incentives to each sector which significantly beneficial for every firm but in emerging economies, due to unstable governmental position researchers gives very little attention towards government and political support (financial, tax incentives, social support, IT, etc.) to gain sustainable competitive performance (Han et al., 2017; Songling et al., 2018); therefore, sufficient government support such as loan schemes, incentives, and training institutions play a vital role for organizational networking system in global and internal levels. Hence, we proposed the model that "Does government support matter? On the relation between networking structure and firm performance in emerging economies.

Consequently, there is an extensive need to study the role of networking structure and government support for the survival of SMEs. As posited by Resource Base View 
(RBV) theory, organizational resources (tangible and intangible) which enable the organization to gain sustainable competitive advantage and high-profit (Barney, 1991). While social network theory determines that the tie with internal and external resources (political and financial institutions) and so forth can push the valuable resources which enhance the firm's performance (Burt, 2000). Hence, this study, based on the RBV theory and social network theory, is a challenge to evaluate how government support can reinforce the relationship between networking structure and organizational competitive advantage. The findings of the current study recommend many suggestions to the policy-maker and governmental institutions to build a strong networking tie with external resources, and governmental institutions (SMEDA) fully support these organizations to gain sustainable competitive performance because SMEs are the driving force of economic growth (Meressa, 2020).

This research is organized as follows: first, it discusses the background, importance of the study, and theoretical background. In the proceeding section, the hypothesis development, methodology, and analysis are discussed. Finally, the discussion, contributions, and conclusion are presented.

\section{Hypothesis development}

\section{Network structure and sustainable competitive performance}

In the business world, a networking tie is defined as established association with suppliers, customers, and competitors without networking roots, and a firm cannot compete with a competitor in the turbulence market. In addition, networking helps to solve the financial and non-financial issues of the organization at global and international levels (Le and Nguyen, 2009) to gain sustainable competitive advantage. Furthermore, networking promotes actual and potential resources rooted within and gains these resources derived with the help of networking system (Nahapiet \& Ghoshal, 1998). Hence, Wu, Wang, Chen, and Pan (2008) suggested that an organizational external networking system significantly contributes to gain a competitive advantage. The networking system of any firm with financial institution is an essential factor, because SMEs intrinsically have a lack of finance. Due to unlimited resources, managers apply different policies for support and networks system and acquire information to develop the business strategy (Franco, Haase, \& Pereira, 2016). Networks facilitate actors for easy access to resources such as information, management skills, equipment, and technology (Gnyawali \& Madhavan, 2001). This alliance can help SMEs to gain a sustainable competitive advantage in emerging economies (Watson, 2007). Besides networking assistances help identify the opportunities, new ideas, and innovativeness to achieve their objective (Lee, Lee, \& Pennings, 2001). Hence, Naudé, Zaefarian, Tavani, Neghabi, and Zaefarian (2014) postulate that firm networking system and performance has a positive strong correlation with each other within the context of SMEs and minimize the SME's failure ratio and increase success rate (Watson, 2007). Therefore, those firms which have long roots of networking in the turbulence market has a positive influence on firm performance in Pakistan (Hanif \& Irshad, 2018; Stam, Arzlanian, \& Elfring, 2014). Similarly, clustered networking especially plays a vital role in the collaboration of information, gaining knowledge, resources, or competitive advantage (Wang, Zhao, Li, \& Li, 2015). 
The organizational networking structure is split into two subparts (density and centrality). First, networking density which explains the range of relationships among thespians (Gnyawali \& Madhavan, 2001). High density represents strong ties of relationships with suppliers to exchange information and resources (Tseng, Lin, Pai, \& Tung, 2016). Second, networking centrality defines an individual thespian's in the networking system (Gnyawali \& Madhavan, 2001). It explains that the range of covers the entire range of network (Wang et al., 2015), similarly, to gain a high degree of organizational resources; it depends on the high level of networking system with suppliers or customers in national/international level (Ibarra, 1993).

Similarly, the networking system supports the organization, to get benefits from tangible and intangible resources (Peng \& Luo, 2000). In addition, political ties define "the association with government bureaucrats and political leaders supporting organizations" (Li, Zhou, \& Shao, 2009) and it helps to increase the economic growth in underdeveloped economies. Hence, past literature notions posit that networking density and centrality significantly contribute to the SME sector and gain sustainable competitive performance, including innovation (Naudé et al., 2014; Tseng et al., 2016; Wang \& Fang, 2012). Wang et al. (2015), especially, highlight that network centrality significant and positive impact on both organizational innovations using meta-analysis based on 40 samples. Therefore, from past literature, we posit the following hypotheses:

$\mathrm{H}_{1}$ : Network density has a positive effect on sustainable competitive advantage.

$\mathrm{H}_{2}$ : Network centrality has a positive effect on sustainable competitive advantage.

\section{Government support and sustainable competitive performance}

Governments promote the SME sector through different types including tax reliefs, loans, social support, and financial support so far (Storey \& Tether, 1998). Social network theory by Burt (2000) suggested that organizations that have strong external networking ties with other firms or institutions national/international can easily gain a substantial number of resources, which is very fruitful for competitive advantage. While resource-based view theory by Barney (1991) suggested that firms gain sustainable and competitive advantage on their competitor in the emerging economy, who have rare and inimitable resources. Furthermore, Sheng, Zhou, and Li (2011) suggested that government incentives play a vital role to surge a sustainable competitive performance in emerging economies. Hence, government incentives and development projects significantly contribute to firms' performance (Wei \& Liu, 2015).

Furthermore, the government's financial supports promote the SME sector to expand its operation to the international level; it can increase the SME's performance and significantly contribute to economic growth (Clement \& Hansen, 2003). Lee (2007) suggested that firm performance significantly dependent on the political and government ties in emerging economies and a firm can gain sustainable production. Moreover, top management, which has strong political and government relationships, can quickly gain a sustainable competitive advantage in the turbulence market ( $\mathrm{Li}$, Meng, Wang, \& Zhou, 2008).

Government support not only to promotes quick access to resources but also supports SME's financial and non-financial at underdeveloped stages (Hansen, Rand, \& 
Tarp, 2009). Fajnzylber, Maloney, and Montes-Rojas (2009) suggested that credit, training, services, loan, tax payment, etc. cannot enhance the organizational performance but in fact, it is an important driver to gain sustainable performance. Hence, from past literature, we posit that government financial and non-financial support significantly improves the innovative capability (Ma \& Gao, 1997). However, government support plays a decisive role in the improvement of organizational performance (Han et al,, 2017). A strong emphasis on government support through technological development in the organization can significantly contribute to firms' growth (Guan \& Yam, 2015). Especially, government financial incentive is deemed a significant factor to surge innovation in developed and developing economies (Mustar \& Larédo, 2002; Wei \& Liu, 2015).

Hence, we claim that a firm having support from the government can gain high performance in dynamic markets. Therefore,

$\mathrm{H}_{3}$ : Government support has a positive impact on sustainable competitive performance.

\section{Mediation}

Previous studies reveal that networking system supports organizational resources and policies to gain a sustainable competitive advantage in turbulence (Desai \& Shaikh, 2018) because networking tie can make easy towards resources (internal and external) (Sheng et al., 2011). In addition, networking facilitates the firm's connection, and well communication with buyers and suppliers, thereby, organizations need some external support to gain a sustainable competitive advantage in emerging economies (Songling et al., 2018). Therefore, previous studies by Desai and Shaikh (2018) postulate that government support plays a vital role as external resources in the form of including tax reliefs, allowances, loans, social, and financial support so far because it significantly contributes in SMEs performance, underpinning through the social network theory and resource-based view theory. Furthermore, social network theory by Burt (2000) explains that organizational strong networking ties with governments institutions can be helpful for gaining sustainable competitive advantage in turbulence market, while resourcebased view theory (Barney 1991) postulates that organizations which have unique, rare, and inimitable resources support SMEs to gain sustainable competitive performance in emerging economies.

In addition, previous literature speculated that networking with government bodies directly effects on the firm performance (Cano-Kollmann, Hamilton III, \& Mudambi, 2017), whether a firm has a strong government and political support but neither networking system then it cannot compete for the competitor in the emerging economies (Holl \& Rama, 2012). Networking net with social peers exposes a small enterprise to create new ideas and different business new ideas for exploiting new investment opportunities (Aldrich and Zimmer, 1986). It is likely that during the process of searching new ideas or breaks, the top management calls for help the political or government support for information because the market is saturated from the various approaches and opportunities, then it helps the management for accurate decision (Adomako, Danso, Boso, \& Narteh, 2018). Therefore, Jugend et al. (2018) suggested that besides 
government support, the firm could not complete the networking system for gaining sustainable competitive performance, especially in emerging economies, and the government supports the firm via different sort of financial, informational, and technological support for competing for the competitor in the turbulence market (Li \& Atuahene-Gima, 2001). Hence, we posit from the past literature that government support links the relationship between networking density and centrality sustainable competitive performance.

$\mathrm{H}_{4}$ : Government support significantly mediates the relationship between network density and sustainable competitive advantage

$\mathrm{H}_{5}$ : Government support significantly mediates the relationship between network centrality and sustainable competitive advantage (Fig. 1)

\section{Methodology}

\section{Sample and data}

This study relies on small- and medium-sized enterprises from the manufacturing sector but precisely we targeted manufacturing small- and medium-sized enterprises from twin cities, Islamabad and Rawalpindi, because most SMEs' head offices are located in these areas. Registered SMEs lists were acquired from the Islamabad chamber of commerce and industry and Rawalpindi chamber of commerce and industry, verified from SMEDA $^{1}$. Structured questionnaires were used to collect the data for 3 months from 1 May to 30 July 2019, from top management because they are more responsible for strategic planning and decision-making (Tajeddini \& Mueller, 2012). A total of 540 questionnaires were distributed among SMEs operating in twin cities (Krejcie \& Morgan, 1970). Three hundred twenty-six respondents fill the questionnaires, but some of these filled incorrectly and many were having missed the required information. However, only 267 useable responses were considered for analysis, and the rest were excluded as they were incorrectly filled. The response rate achieved in this research was $47.16 \%$.

\section{Measurement of variables}

The current study consists of two independent variables (network density and network centrality): one dependent variable (sustainable competitive performance) and one mediator (government support) (Table 1).

\section{Control variables}

Previous literature suggested few variables such as the size of firms, age of firms, and educational background can be used as control variables (Ying et al. 2019). Control variables mostly help to minimize the spurious results. Considering the mentioned variables as control, the results of the structural model indicate that the size of firms as a mixed effect.

\section{Result analysis}

\section{Descriptive statistics}

The list of the participants is reported in Table 2 below.

${ }^{1}$ Small and Medium Enterprises Development Authority 


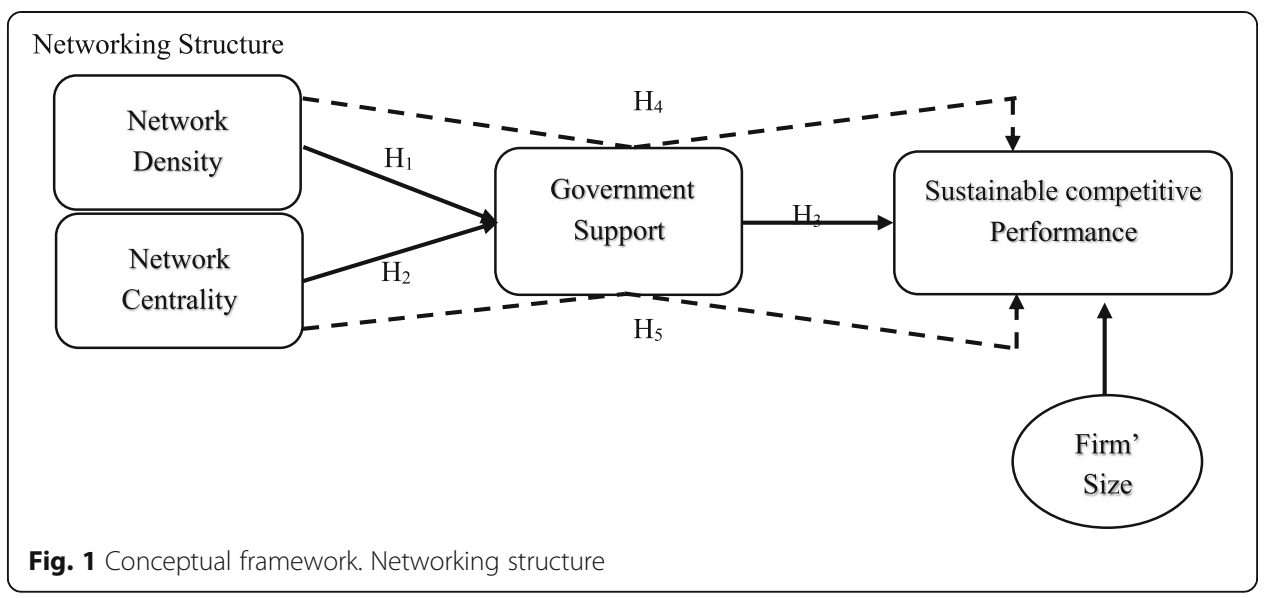

\section{Mean, standard deviation, skewness, and kurtosis}

Table 3 presents a comprehensive description of the descriptive statistical analysis showing the mean (M) and standard deviation (SD) scores, as well as the skewness and kurtosis values. The values of Table 3 reveal that the data present satisfactory results and shows the normal distribution.

\section{Correlation coefficient}

The Pearson correlation of the current study has tested through SPSS. The results indicate that there are positive and significant correlation among network density, network centrality, and sustainable competitive performance such as network structure centrality $(r=0.12, p<0.01)$, network structure density $(r=0.24, p<0.01)$. Furthermore, government support has a positive and significant relationship with sustainable competitive performance such as $(r=0.28, p<0.01)$. Similarly, we found that network structure density has a positive and significant relationship with government support $(r$ $=0.25, p<0.01$ ), while network structure centrality also has a positive and significant correlation with government support $(r=0.47, p<0.01)$. Hence, the overall results show that there is not such a multi-collinearity error in our model because of all value $<0.80$, (see Table 4).

Table 1 Measurement model

\begin{tabular}{|c|c|c|c|c|c|}
\hline No. & Variable name & Explanation & Items & Source & Likert scales \\
\hline 1 & Network density & $\begin{array}{l}\text { The average strength of the relationship in } \\
\text { SMEs networking system }\end{array}$ & 5 & $\begin{array}{l}\text { (Antia \& } \\
\text { Frazier, } \\
\text { 2001) }\end{array}$ & $\begin{array}{l}\text { Disagree } 1 \text {, to } \\
\text { strongly agree } 5\end{array}$ \\
\hline 2 & $\begin{array}{l}\text { Network } \\
\text { centrality }\end{array}$ & $\begin{array}{l}\text { Explains the small enterprise's position in the } \\
\text { networking system }\end{array}$ & 4 & $\begin{array}{l}\text { (Antia \& } \\
\text { Frazier, } \\
\text { 2001) }\end{array}$ & $\begin{array}{l}\text { Disagree } 1 \text {, to } \\
\text { strongly agree } 5\end{array}$ \\
\hline 3 & $\begin{array}{l}\text { Sustainable } \\
\text { competitive } \\
\text { performance }\end{array}$ & $\begin{array}{l}\text { Represents to express their feeling about firm } \\
\text { performance before the last } 3 \text { years }\end{array}$ & 10 & $\begin{array}{l}\text { (Su et al., } \\
2017)\end{array}$ & $\begin{array}{l}\text { Extremely declined, } \\
\text { 1, to extremely } \\
\text { improved, } 5\end{array}$ \\
\hline 4 & $\begin{array}{l}\text { Government } \\
\text { support }\end{array}$ & $\begin{array}{l}\text { The firm can get financing from various } \\
\text { institutions such as banks, financial } \\
\text { institutions, internal funds and angel investors } \\
\text { and so forth }\end{array}$ & 7 & $\begin{array}{l}\text { (Ahmad \& } \\
\text { Xavier, } \\
\text { 2012) }\end{array}$ & $\begin{array}{l}\text { Dissupport 1, to } \\
\text { strongly support } 5\end{array}$ \\
\hline
\end{tabular}


Table 2 Detail of participated SMEs

\begin{tabular}{llll}
\hline Firm's size & & & \\
S/No & Description & Frequency & Percent \\
1 & $10-50$ employees & 109 & 40.1 \\
2 & $51-100$ employees & 123 & 37.5 \\
3 & $101-250$ employees & 65 & 22.5 \\
Firm age & & & \\
S/No & Description & Frequency & Percent \\
1 & 10 years and less & 97 & 41.0 \\
2 & $11-20$ years & 129 & 33.9 \\
3 & 21 years old and above & 41 & 25.1 \\
& Total & 267 & 100.0 \\
\hline
\end{tabular}

Table 3 Mean (M), standard deviation, skewness, and kurtosis

\begin{tabular}{|c|c|c|c|c|}
\hline Items & Mean & Std. deviation (SDs) & Skewness & Kurtosis \\
\hline NS1 & 3.76 & 0.548 & 0.010 & -0.715 \\
\hline NS2 & 3.86 & 0.533 & -0.097 & -0.742 \\
\hline NS3 & 3.65 & 0.533 & -0.097 & -0.742 \\
\hline NS4 & 3.27 & 0.528 & -0.434 & -0.026 \\
\hline SCP1 & 3.86 & 0.515 & -0.392 & -0.651 \\
\hline SCP2 & 3.57 & 0.484 & -0.528 & -0.330 \\
\hline SCP3 & 3.87 & 0.493 & -0.415 & 0.008 \\
\hline SCP4 & 3.27 & 0.491 & -0.475 & -0.624 \\
\hline SCP5 & 3.57 & 0.484 & -0.528 & -0.330 \\
\hline SCP6 & 3.57 & 0.492 & -0.453 & -0.347 \\
\hline SCP7 & 3.27 & 0.499 & -0.399 & -0.615 \\
\hline SCP8 & 3.67 & 0.492 & -0.443 & -0.215 \\
\hline SCP9 & 3.17 & 0.510 & -0.303 & -0.651 \\
\hline SCP10 & 3.67 & 0.487 & -0.490 & -0.252 \\
\hline ND1 & 3.57 & 0.535 & -0.518 & 0.397 \\
\hline ND2 & 3.96 & 0.511 & -0.581 & -0.364 \\
\hline ND3 & 3.77 & 0.502 & -0.670 & 0.509 \\
\hline ND4 & 3.96 & 0.540 & -0.569 & 0.097 \\
\hline ND5 & 3.87 & 0.508 & -0.758 & 0.940 \\
\hline GS1 & 3.38 & 0.412 & -1.159 & 0.974 \\
\hline GS2 & 3.87 & 0.477 & -0.567 & -0.033 \\
\hline GS3 & 3.17 & 0.482 & -0.574 & -0.801 \\
\hline GS4 & 3.97 & 0.449 & -0.836 & 0.103 \\
\hline GS5 & 3.27 & 0.479 & -0.603 & -0.746 \\
\hline GS6 & 3.38 & 0.420 & -1.048 & 0.936 \\
\hline GS7 & 3.77 & 0.472 & -0.622 & -0.072 \\
\hline Total numbers & 267 & & & \\
\hline
\end{tabular}


Table 4 Correlation

\begin{tabular}{lllllllll}
\hline S/No. & Items & 1 & 2 & 3 & 4 & 5 & 6 & 7 \\
\hline 1 & Industry & 1 & & & & & \\
2 & Firm size & 0.019 & 1 & & & & \\
3 & Firm age & 0.102 & $0.15^{\mathrm{a}}$ & 1 & & & \\
4 & Network centrality & 0.089 & 0.05 & $0.15^{\mathrm{b}}$ & 1 & & \\
5 & Network density & 0.097 & $0.22^{\mathrm{b}}$ & $0.22^{\mathrm{b}}$ & $0.24^{\mathrm{b}}$ & 1 & \\
6 & Sustainable competitive performance & 0.019 & $0.19^{\mathrm{b}}$ & $0.12^{\mathrm{a}}$ & $0.12^{\mathrm{a}}$ & $0.24^{\mathrm{b}}$ & 1 \\
7 & Government support & 0.072 & $0.37^{\mathrm{b}}$ & $0.45^{\mathrm{b}}$ & $0.25^{\mathrm{b}}$ & $0.47^{\mathrm{b}}$ & $0.28^{\mathrm{b}}$ & 1 \\
\hline
\end{tabular}

${ }^{a}$ Correlation is significant at the 0.05 level (2-tailed)

${ }^{b}$ Correlation is significant at the 0.01 level (2-tailed)

\section{Measurement model assessment}

In the current study, we used PLS (SEM) 3.0 to evaluate outer (measurement model) and direct, indirect and for mediator analysis while it used to determine causal link in the theoretical model (Ringle et al., 2015). Furthermore, Smart PLS is essential for the model configuration approach in testing the reflective measurement model. Therefore, we explain that all constructs tell more than $50 \%$ of the indicator variance (Table 6). Hence, we know from results that our model is fit (Hair, Risher, Sarstedt, \& Ringle, 2019).

After model fitness, the next step is to check model composite reliability and validity (Hair et al., 2019). Higher values generally show a higher level of reliability, so our results indicate that every construct has greater than 0.70 reliability value (Table 6 ) which is acceptable as suggested by $\mathrm{Hu}$ and Bentler (1999), while convergent validity explains the construct converges the variance of its item. Therefore, AVE acceptable range is higher than 0.50 (Hair et al., 2019). Hence, in our study, AVE results explain that all construct has greater than 0.50 (Table 6), while our results postulate that discriminant validity is also in the acceptable range (0.65 to 0.85$)$ because all construct has greater than 0.70 values (Table 5) (Khan and Ghufran, 2018; Khan, 2019). The same goes to every construct item reliability and convergent validity (Table 6).

\section{Direct effect and hypothesis testing}

The next step in evaluating PLS structure equation model (SEM) results is assessing the structure model. The structure model examines the inner model justification of direct relation among the latent constructs and comprises with path coefficient $(\beta)$ and $t$ value. Hence, our results show that network structure density has a positive and significant relation with sustainable competitive performance $(\beta=22, p=0.00)$, while centrality has an insignificant association with durable competitive production $(\beta=23, p=$ 0.06) (see Table 7). So, as of the current results, we accept $\mathrm{H}_{2}$ and reject $\mathrm{H}_{1}$.

Table 5 Discriminant validity

\begin{tabular}{lllll}
\hline Items & SCP & GS & NSC & NCD \\
\hline Sustainable competitive performance & $\mathbf{0 . 8 5 0}$ & & & \\
Government support & 0.311 & $\mathbf{0 . 7 6 9}$ & & \\
Networking centrality & 0.115 & 0.180 & $\mathbf{0 . 8 6 0}$ & \\
Networking density & 0.247 & 0.494 & 0.044 & $\mathbf{0 . 7 8 0}$ \\
\hline
\end{tabular}


Table 6 Measurement model, reliability, and validity

\begin{tabular}{|c|c|c|c|c|c|}
\hline S/No. & Items & Factor loading & Cronbach's alpha & Composite reliability & $A V E^{a}$ \\
\hline \multicolumn{6}{|c|}{ Networking centrality } \\
\hline 1 & NS1 & 0.816 & 0.83 & 0.894 & 0.739 \\
\hline 2 & NS2 & 0.907 & & & \\
\hline 3 & NS3 & 0.847 & & & \\
\hline \multicolumn{6}{|c|}{ Networking density } \\
\hline 1 & NSD1 & 0.776 & 0.84 & 0.884 & 0.605 \\
\hline 2 & NSD2 & 0.747 & & & \\
\hline 3 & NSD3 & 0.755 & & & \\
\hline 4 & NSD4 & 0.782 & & & \\
\hline 5 & NSD5 & 0.828 & & & \\
\hline \multicolumn{6}{|c|}{ Sustainable competitive performance } \\
\hline 1 & SCP1 & 0.697 & 0.94 & 0.959 & 0.722 \\
\hline 10 & SCP10 & 0.917 & & & \\
\hline 2 & SCP2 & 0.842 & & & \\
\hline 4 & SCP4 & 0.911 & & & \\
\hline 5 & SCP5 & 0.905 & & & \\
\hline 6 & SCP6 & 0.888 & & & \\
\hline 7 & SCP7 & 0.875 & & & \\
\hline 8 & SCP8 & 0.888 & & & \\
\hline 9 & SCP9 & 0.686 & & & \\
\hline \multicolumn{6}{|c|}{ Government support } \\
\hline 2 & GS2 & 0.68 & 0.87 & 0.896 & 0.591 \\
\hline 3 & GS3 & 0.88 & & & \\
\hline 4 & GS4 & 0.65 & & & \\
\hline 5 & GS5 & 0.87 & & & \\
\hline 6 & GS6 & 0.74 & & & \\
\hline 7 & GS7 & 0.77 & & & \\
\hline
\end{tabular}

${ }^{\text {aAverage variance extracted }}$

Similarly, our results explain that mediator (government support) has a positive and significant relation with sustainable competitive performance $(\beta=0.413, p<0.01)$; hence, due to our current results, we suppose that $\mathrm{H}_{3}$ is supported (see Table 8).

Furthermore, during mediation, our results postulate that government financial support significantly partially mediates the relation between networks structure density and sustainable competitive performance $(\beta=0.39, p<0.00)$, while it also partially mediates the relationship between networks structure centrality and sustainable competitive performance $(\beta=0.443, p=0.026)$. Hence, we proposed that $\mathrm{H}_{4}$ and $\mathrm{H}_{5}$ both are supported (see Table 9).

Table 7 Hypothesis direct relation

\begin{tabular}{llllllllll}
\hline Hypotheses & Path & Beta & Mean & S. D & T Statis & $p$ value & $R^{2}$ & $F^{2}$ & Decision \\
\hline & Firm age $->$ SCP & 0.138 & 0.127 & 0.055 & 2.372 & 0.258 & 0.083 & 0.01 & \\
$\mathrm{H}_{2}$ & NC $\rightarrow$ SCP & 0.228 & 0.139 & 0.095 & 1.433 & 0.091 & & 0.058 & Non-support \\
$H_{1}$ & ND $\rightarrow$ SCP & 0.217 & 0.225 & 0.054 & 3.992 & 0.000 & & 0.018 & Support \\
\hline
\end{tabular}


Table 8 Government support and SCP direct relation

\begin{tabular}{llllllllll}
\hline Hypotheses & Path & Beta & Mean & S.D. & T Statis & $p$ value & $R^{2}$ & $F^{2}$ & Decision \\
\hline & Firm age $->$ SCP & -0.12 & 0.127 & 0.055 & 2.372 & 0.258 & 0.192 & 0.01 & \\
$\mathrm{H}_{3}$ & GS $\rightarrow$ SCP & 0.413 & 0.324 & 0.056 & 0.580 & 0.000 & & 0.087 & Support \\
\hline
\end{tabular}

\section{Discussion}

The current study examines the influence of networking structure on sustainable competitive performance in the Pakistani context, and government support matters in this relationship. Finally, we found that our results are very equivocal. Because many researchers have studied that, but the role of sustainable competitive performance has been ignored especially in manufacturing sectors because in Pakistan, 73\% are operationalized organizations in different sectors (Hassan et al., 2017). In sporadic cases, the researchers examined the role of specific networking structure underpin with resourcebased view theory (RBV) and social network theory. Our results contradict with previous research conducted by Kim \& Lee, 2018 on Korean SMEs convergence association, which found that all networking structure has positively and significantly with SMEs success, and we discussed many of the similarities and differences below.

Even among the networking structure dimensions, our results explain that network density has a positive and significant effect on sustainable competitive performance; hence, our finding is consistent with the previous literature conducted by Kim \& Lee, 2018; Wang \& Fang, 2012; Naudé et al., 2014; Lee 2007; Tsai, 2001; Wang, Zhao, Li and Li, 2015. It posits that if Pakistani's manufacturing sectors' small enterprises have a strong relation with ventures at the national and international levels, therefore it significantly contributes to SME's performance. Hence, we support the argument that network structure density has a positive and significant effect on sustainable competitive performance in Pakistani manufacturing sector firms.

Furthermore, our results explain that networking centrality has insignificant $(\beta=$ $0.13, p<0.05)$ effect on sustainable competitive performance. Hence, $\mathrm{H}_{2}$ is not supported. In addition, our study finding supports the study conducted by Adomako et al., 2018 who scrutinized that if a firm has a large number of networking roots with international or local firms, sometimes these pools of connection create barriers during target achievement in a sustainable competitive market (Rodrigues, 2019). On the other side, many kinds of literature explain that network structure centrality has a strong and positive impact on firm performance, and these studies are primarily conducted in developed countries (Kim \& Lee, 2018; Wang, Zhao, Li and Li, 2015). Nevertheless, the current research was conducted in developed countries (Pakistan) which are the pool of challenges for managers and owners. Hence, as in the light of Rodrigues, 2019, we suggest that network structure centrality has an insignificant effect on sustainable competitive performance in Pakistan.

Table 9 Total Mediation relation

\begin{tabular}{llllllllll}
\hline Hypothesis & Path & Beta & Mean & S.D. & T Statis & $p$ value & $R^{2}$ & $F^{2}$ & Decision \\
\hline $\mathrm{H}_{4}$ & $\mathrm{NC} \rightarrow>\mathrm{GS}->\mathrm{SCP}$ & 0.443 & 0.045 & 0.022 & 1.950 & 0.026 & 0.082 & 0.027 & Support \\
$\mathrm{H}_{5}$ & $\mathrm{ND} \rightarrow>\mathrm{GS} \rightarrow \mathrm{SCP}$ & 0.387 & 0.152 & 0.038 & 3.882 & 0.000 & & 0.313 & Support \\
\hline
\end{tabular}


In addition, the results show that government support has a strong positive and significant $\left(\beta=313, p<0.01\right.$ ) impact on sustainable competitive performance. Hence, $\mathrm{H}_{3}$ is supported. Similarly, hypothesis 3 also buttresses the previous studies conducted by Doh \& Kim, 2014; Wei \& Liu, 2015. So, our results postulate that a firm has strong network ties with political and government bodies in developing economies can give a higher sustainable competitive advantage as compared to those who have weak connections with government and governmental agencies (Fan et al., 2007). The current results scrutinized that if managers had strong ties with legislative and government institutions in developing countries, they could enjoy a high return rate and higher growth rate (Li et al., 2008). Finally, we suggest that government financial support has a significant positive effect on sustainable competitive performance in developing economies.

We found that government support positively and significantly supports the relation among network structure density, network centrality, and sustainable competitive performance in developing countries; hence, $\mathrm{H}_{4}$ and $\mathrm{H}_{5}$ are supported. In line with Jugend et al., 2018, who posit that managers or owners who have a weak networking system could improve on behalf of the government and political bodies and can gain his long-term goals in the turbulent market. The government offers incentives, subsidies; taxes and credits incentives that can promote managers' and owners' networking ties towards achieving long-term goals (Adomako et al., 2018). Hence, we suggest that if a firm has government financial incentives and subsidies, it can make the relationship between networking ties and competitive performance in Pakistan stronger.

\section{Conclusion}

This study examines the effect of networking dimensions (density and centrality) on sustainable competitive performance in the manufacturing sector. In emerging economies, mostly organizational top managers and owners are trying to connect networking his roots at the national and international levels, but still organization faces a lack of government support. The research is based on resource-based view theory (RBV), where the role of network structure on SCP and mediating role of government financial support are tested. For fruitful results, we collected data through structured questionnaires from responsible bodies (top managers and policy-makers). After analyzing through Smart PLS, we found that network structure density has a positive and significant effect on SCP but centrality, without any external support, centrality did not have a significant impact on SCP in Pakistani contests. While government financial support strong positive support between centrality and sustainable competitive performance, furthermore, GFS has strong positive support between network structure density and SCP. In addition, our results contradict the study conducted by Kim \& Lee, 2018 and strongly support the study by Hassan et al., 2017. This study recommended several implications for government, top managers, financial institutions, and SMEDA. Hence, we suggest some implications to the government that encourage SMEs top management and owners to build a strong network clustered with local and international levels because China-Pakistan Economic Corridor (CPEC) is going to launch his operation very soon. 


\section{Practical implication}

This research advocates several implications for managers, owners, policymakers, and responsible bodies to focus on local and international networking ties. Our study results confirm that networking structure (density and centrality) ensures government financial support and can boost sustainable competitive performance. Therefore, the research delineates that if a firm has weak networking roots (density and centrality), it can be substantial by government support such as credit or tax incentives and subsidies to gain sustainable competitive performance in developing economies. In Pakistani contacts, mostly small enterprises of the manufacturing sector have lack of networking cluster with local or international firms; hence, government supports owners, policy-makers, and managers of small enterprises to offer the creation of creating new networking clustered at domestic and international level for the development of new products, new services, and technological adaption to survive in the turbulence market.

In addition, we suggest a few practical implications for top management and policymakers of SMEs who face big challenges regarding networking clustered; following our study results, it recommends to build strong networking ties with government and political bodies. Top managers and owners of SMEs are recommended to spread his networking roots up to local and international levels and build a strong relation with political and government bodies because it helps to gain the sustainable objective of the firm. In emerging economies, our results recommended that governments play a vital role to build networking clustered at the international level in Pakistan, because the board of directors of Pakistan's firm has no such strong position to create networking ties.

Moreover, this research strongly recommends the Small-Medium Enterprises Development Authority (SMEDA) to modify their strategies and policies to encourage the relationship between foreign and local firms. For instance, CPEC (China-Pakistan Economic Corridor) is going to launch its operation very soon. This trade route will result in large transactions in international markets. Therefore, SMEDA and the government need to keep the SMEs ready for this opportunity (e.g., CPEC) to get benefits of global technology, international finance, international experience, and networking. This study does not only encourage SMEs and policy-makers in the emerging market of Pakistan but also gives equal weight to the importance of certain international resources and capabilities in other countries.

\section{Limitation and pathway for future direction}

The current study is not free from limitations because it has significant implications in the current era but still it has several limitations. The current study conducted in a single emerging country Pakistan that may not deem the whole representative of Islamic emerging countries. Hence, more evidence can be collected from emerging and developed economies because every country has its different categories of subsidies, incentives for top management, and policymaker of a firm, which can affect top management networking clustered with international and local firms. In the current study, we just targeted small enterprises but, in the future, we recommended testing the model in a startup venture, because small venture faces a lot of barriers regarding networking clustered in emerging economies. In the future, the researcher can extend the study through, collecting cross-sectional data from Islamic and non-Islamic emerging economies because these results will be must clarify the small venture challenges. 


\section{Abbreviations}

SCP: Sustainable competitive performance; GS: Government support; SMEDA: Small-Medium Enterprises Development Authority; NSD: Networking structure density; NSC: Networking structure centrality

\section{Acknowledgements}

We are very thankful to the Institute of Postgraduate Studies (IPS) of Universiti of Sains Malaysia to provide us a good study environment.

\section{Authors' contributions}

RUK has developed the model and has written the original draft. AA wrote the original draft and helped during the editor comments amendments and NN helped during the technical problems of the manuscript. All authors read and approved the final manuscript.

\section{Funding}

This research received no external funding

\section{Availability of data and materials}

We collected the data from small to medium enterprises of various cities in Pakistan. Please note that we can also avail of the do-files upon request.

\section{Competing interests}

The authors declare that they have no competing interests.

Received: 6 October 2019 Accepted: 27 July 2020

Published online: 27 August 2020

\section{References}

Adomako, S., Danso, A., Boso, N., \& Narteh, B. (2018). Entrepreneurial alertness and new venture performance: Facilitating roles of networking capability. International Small Business Journal, 36(5), 453-472.

Ahmad, S. Z., \& Xavier, S. R. (2012). Entrepreneurial environments and growth: evidence from Malaysia GEM data. Journal of Chinese Entrepreneurship, 4, 50-69.

Aldrich, H., and Zimmer, C. (1986). Entrepreneurship through social networks. In D.L. Sexton and R.W. Smiler, eds., The Art and Science of Entrepreneurship (pp. 2-23). Cambridge, MA: Ballinger.

Antia, K. D., \& Frazier, G. L. (2001). The severity of contract enforcement in interfirm channel relationships. Journal of Marketing, 65(4), 67-81.

Anwar, M., Khan, S. Z., \& Khan, N. U. (2018). Intellectual capital, entrepreneurial strategy and new ventures performance: Mediating role of competitive advantage. Business and Economic Review, 10(1), 63-93.

Barney, J. (1991). Firm resources and sustained competitive advantage. Journal of management, 17(1), 99-120.

Bilal, A. R., Khan, A. A., \& Akoorie, M. E. M. (2016). Constraints to growth: A cross country analysis of Chinese. Chinese Management Studies: Indian and Pakistani SMEs.

Burt, R. S. (2000). The network structure of social capital. Research in Organizational Behavior, 22, 345-423.

Cano-Kollmann, M., Hamilton III, R. D., \& Mudambi, R. (2017). Public support for innovation and the openness of firms' innovation activities. Industrial and Corporate Change, 26(3), 421-442.

Clement, K., \& Hansen, M. (2003). Financial incentives to improve environmental performance: A review of Nordic public sector support for SMEs. European Environment, 13(1), 34-47.

Desai, D. A., \& Shaikh, A. J. A. (2018). Reducing failure rate at high voltage (HV) testing of insulator using six sigma methodology. International Journal of Productivity and Performance Management.

Doh, S., \& Kim, B. (2014). Government support for SME innovations in the regional industries: The case of government financial support program in South Korea. Research Policy, 43(9), 1557-1569.

Fajnzylber, P., Maloney, W. F., \& Montes-Rojas, G. V. (2009). Releasing constraints to growth or pushing on a string? Policies and performance of Mexican micro-firms. The Journal of Development Studies, 45(7), 1027-1047.

Fan, J. P., Wong, T. J., \& Zhang, T. (2007). Politically connected CEOs, corporate governance, and post-IPO performance of China's newly partially privatized firms. Journal of Financial Economics, 84, 330-357.

Franco, M., Haase, H., \& Pereira, A. (2016). Empirical study about the role of social networks in SME performance Journal of Systems and Information Technology.

Gnyawali, D. R., \& Madhavan, R. (2001). Cooperative networks and competitive dynamics: A structural embeddedness perspective. Academy of Management Review, 26(3), 431-445.

Guan, J., \& Yam, R. C. (2015). Effects of government financial incentives on firms' innovation performance in China: Evidences from Beijing in the 1990s. Research Policy, 44(1), 273-282.

Hair, J. F., Risher, J. J., Sarstedt, M., \& Ringle, C. M. (2019). When to use and how to report the results of PLS-SEM. European Business Review.

Han, Y. J., Chung, J. Y., Son, J. S., \& Kwon, S. J. (2017). The effects of the innovation types of venture firms and government support on firm performance and new job creation: Evidence from South Korea Academy of Strategic Management Journal.

Hanif, M. I., \& Irshad, M. (2018). Impact of entrepreneurial orientation and network resource utilization on internationalization of SME; ${ }^{-}$s: Evidence from Pakistan. International Journal of Marketing Studies, 10(2), 118-131.

Hansen, H., Rand, J., \& Tarp, F. (2009). Enterprise growth and survival in Vietnam: Does government support matter? The Journal of Development Studies, 45(7), 1048-1069.

Hassan, M. T., Burek, S., \& Asif, M. (2017). Barriers to industrial energy efficiency improvement-manufacturing SMEs of Pakistan. Energy Procedia, 113, 135-142.

Holl, A., \& Rama, R. (2012). Technology sourcing: Are biotechnology firms different? An exploratory study of the Spanish case. Science and Public Policy, 39(3), 304-317. 
Hoque, A. S. M. M. (2018). Does government support policy moderate the relationship between entrepreneurial orientation and Bangladeshi SME performance? A SEM approach. International Journal of Business Economics and Management Studies, 6(3), 37-59.

Hu, L. T., \& Bentler, P. M. (1999). Cutoff criteria for fit indexes in covariance structure analysis: Conventional criteria versus new alternatives. Structural Equation Modeling: A Multidisciplinary Journal, 6(1), 1-55.

Ibarra, H. (1993). Network centrality, power, and innovation involvement: Determinants of technical and administrative roles. Academy of Management Journal, 36(3), 471-501.

Joo, H. Y., \& Suh, H. (2017). The effects of government support on corporate performance hedging against international environmental regulation. Sustainability, 9(11), 1980.

Jugend, D., Jabbour, C. J. C., Scaliza, J. A. A., Rocha, R. S., Junior, J. A. G., Latan, H., \& Salgado, M. H. (2018). Relationships among open innovation, innovative performance, government support and firm size: Comparing Brazilian firms embracing different levels of radicalism in innovation. Technovation, 74, 54-65.

Khan, R. U. (2019). Relationship of HR practices and career path: A perspective of accounting studies. Jinnah Business Review, $7(1), 46-56$.

Khan, R. U., \& Ghufran, H. (2018). The mediating role of perceived organizational support between qualitative job insecurity, organizational citizenship behavior and job performance. Journal of Entrepreneurship and Organization Management, 7(1), $228-235$.

Kim, C., \& Lee, J. (2018). The effect of network structure on performance in South Korea SMEs: The moderating effects of absorptive capacity. Sustainability, 10(9), 3174

Krejcie, R. V., \& Morgan, D. W. (1970). Determining sample size for research activities. Educational and Psychological Measurement, 30(3), 607-610.

Le, N. T., \& Nguyen, T. V. (2009). The impact of networking on bank financing: The case of small and medium-sized enterprises in Vietnam. Entrepreneurship theory and practice, 33(4), 867-887.

Lee, C., Lee, K., \& Pennings, J. M. (2001). Internal capabilities, external networks, and performance: A study on technologybased ventures. Strategic Management Journal, 22(6-7), 615-640.

Lee, G. K. (2007). The significance of network resources in the race to enter emerging product markets: The convergence of telephony communications and computer networking, 1989-2001. Strategic Management Journal, 28(1), 17-37.

Li, H., Meng, L., Wang, Q., \& Zhou, L. A. (2008). Political connections, financing and firm performance: Evidence from Chinese private firms. Journal of Development Economics, 87(2), 283-299.

Li, J. J., Zhou, K. Z., \& Shao, A. T. (2009). Competitive position, managerial ties, and profitability of foreign firms in China: An interactive perspective. Journal of International Business Studies, 40(2), 339-352.

Li, H., \& Atuahene-Gima, K. (2001). Product innovation strategy and the performance of new technology ventures in China. Academy of Management Journal, 44(6), 1123-1134.

Ma, C., \& Gao, C. (1997). Technical innovation and economics. Sci. Technol. Rev, 4, 18-22.

Mbonyane, B., \& Ladzani, W. (2011). Factors that hinder the growth of small businesses in south African townships. European Business Review.

Meressa, H. A. (2020). Growth of micro and small-scale enterprises and its driving factors: Empirical evidence from entrepreneurs in emerging region of Ethiopia. Journal of Innovation and Entrepreneurship, 9(1), 1-22.

Mustar, P., \& Larédo, P. (2002). Innovation and research policy in France (1980-2000) or the disappearance of the Colbertist state. Research Policy, 31(1), 55-72.

Nahapiet, J., \& Ghoshal, S. (1998). Social capital, intellectual capital, and the organizational advantage. Academy of Management Review, 23(2), 242-266.

Naudé, P., Zaefarian, G., Tavani, Z. N., Neghabi, S., \& Zaefarian, R. (2014). The influence of network effects on SME performance. Industrial Marketing Management, 43(4), 630-641.

Peng, M. W., \& Luo, Y. (2000). Managerial ties and firm performance in a transition economy: The nature of a micro-macro link. Academy of Management Journal, 43(3), 486-501.

Pruthi, S., \& Wright, M. (2017). Social ties, social capital, and recruiting managers in transnational ventures. Journal of East-West Business, 23(2), 105-139.

Ringle, C. M., Wende, S., \& Becker, J. M. (2015). SmartPLS 3. Boenningstedt: SmartPLS GmbH.

Rodrigues, F. A. (2019). Network centrality: An introduction, In A Mathematical Modeling Approach from Nonlinear Dynamics to Complex Systems (pp. 177-196) (). Cham: Springer.

Sheng, S., Zhou, K. Z., \& Li, J. J. (2011). The effects of business and political ties on firm performance: Evidence from China. Journal of Marketing, 75(1), 1-15.

Songling, Y., Ishtiaq, M., Anwar, M., \& Ahmed, H. (2018). The role of government support in sustainable competitive position and firm performance. Sustainability, 10(10), 3495.

Stam, W., Arzlanian, S., \& Elfring, T. (2014). Social capital of entrepreneurs and small firm performance: A meta-analysis of contextual and methodological moderators. Journal of Business Venturing, 29(1), 152-173.

Storey, D. J., \& Tether, B. S. (1998). Public policy measures to support new technology-based firms in the European Union. Research Policy, 26(9), 1037-1057.

Su, Z., Guo, H., \& Sun, W. (2017). Exploration and firm performance: The moderating impact of competitive strategy. British Journal of Management, 28(3), 357-371.

Tahir, M., Batool, S., \& Takrim, K. (2016). The effects of total quality management on exports in manufacturing based small and medium enterprise's: A case study of organizations from selected regions of Pakistan. NUML International Journal of Business \& Management, 11(1), 173-197.

Tajeddini, K., \& Mueller, S. L. (2012). Corporate entrepreneurship in Switzerland: Evidence from a case study of Swiss watch manufacturers. International Entrepreneurship and Management Journal, 8(3), 355-372.

Tsai, W. (2001). Knowledge transfer in intraorganizational networks: Effects of network position and absorptive capacity on business unit innovation and performance. Academy of Management Journal, 44(5), 996-1004.

Tseng, C. Y., Lin, S. C., Pai, D. C., \& Tung, C. W. (2016). The relationship between innovation network and innovation capability: A social network perspective. Technology Analysis \& Strategic Management, 28(9), 1029-1040. 
Wang, H., Zhao, J., Li, Y., \& Li, C. (2015). Network centrality, organizational innovation, and performance: A meta-analysis. Canadian Journal of Administrative Sciences/Revue Canadienne des Sciences de l'Administration, 32(3), 146-159.

Wang, M. C., \& Fang, S. C. (2012). The moderating effect of environmental uncertainty on the relationship between network structures and the innovative performance of a new venture. Journal of Business \& Industrial Marketing.

Watson, J. (2007). Modeling the relationship between networking and firm performance. Journal of Business Venturing, 22(6), $852-874$.

Wei, J., \& Liu, Y. (2015). Government support and firm innovation performance: Empirical analysis of 343 Waluszewski, A. "hoping for network effects or fearing network effects.". The IMP Journal 1, no., 1(2006), 71-84.

Wu, L. Y., Wang, C. J., Chen, C. P., \& Pan, L. Y. (2008). Internal resources, external network, and competitiveness during the growth stage: A study of Taiwanese high-tech ventures. Entrepreneurship Theory and Practice, 32(3), 529-549.

Ying, Q., Hassan, H., \& Ahmad, H. (2019). The role of a manager's intangible capabilities in resource acquisition and sustainable competitive performance. Sustainability, 11(2), 527.

\section{Publisher's Note}

Springer Nature remains neutral with regard to jurisdictional claims in published maps and institutional affiliations.

Submit your manuscript to a SpringerOpen ${ }^{\circ}$ journal and benefit from:

- Convenient online submission

- Rigorous peer review

- Open access: articles freely available online

- High visibility within the field

- Retaining the copyright to your article

Submit your next manuscript at $\boldsymbol{\nabla}$ springeropen.com 